\title{
Study of reproduction cycles and yield dynamics of the classical swine fever virus in PK-15 cultured cells using a fluorescent probes technique
}

\author{
L. D. Reshetniak, E. A. Krasnobayev, E. V. Novozhilova, \\ E. N. Zherebtsova, G. A. Popova
}

Institute of Veterinary Medicine of the Ukrainian Academy of Agriculture 30 Donets'ka str., Kyiv, 03151, Ukraine

The authors have elaborated some methodological approaches necessary to solve certain biotechnological
problems. This approaches permit to study the classical swine fever virus reproduction and accumulation
in a swine established cell line, PK-IS, the virus propagation being accompanied with no cytopathic effect.
The reliable and promising fluorescent probe technique needing no previous virus adaptation and
multiplication in permissive cells is successfully confirmed to be useful for such purposes.

Introduction. The classical swine fever (CSF) caused by the homonymous RNA-containing virus (CSFV), a member of Pestivirus genus (Flaviviridae family), is still among the most dangerous swine infections. The widest investigations concerning recombinant vaccine construction are now carrying out. However, such vaccines are not yet completely studied. In some countries belonging to the former Soviet Union several anti-CSFV vaccines have been elaborated and are now produced containing vaccine virus strains. To construct any up-to-date antiviral vaccines aimed for the CSF prevention, a biotechnological problem of the large scale CSFV cultivation followed by a high virus yield is to be successfully solved. The solving of this problem, however, is almost impossible without full information concerning reproductive cycles of both vaccine and virulent CSFV strains; such information is to be obtained using virus-sensitive cell culture infection.

The in vitro CSFV reproduction has been previously investigated with a fluorescent antibody approach [1], the virus reproduction having been registered according to fluorescent foci appearance on the cell monolayer surface: a reproduction curve presented in the paper [1] gives, however, no possibility to

C L. D. RESHETNIAK, E. A. KRASNOBAYEV, E. Y. NOVOZHILOVA E. N. ZHEREBTSOVA, G. A. POPOVA, 1999 understand clearly the dynamics of the CSFV accumulation in infected cells. Some biological properties of the CSFV including also its in vitro multiplication accompanied by no cytopathic effect (CPE), its intimate association with cell membranes, and usual low virus yields make difficult any investigation concerning both CSFV reproduction cycles and its accumulation dynamics. The CSFV as well as the bovine viral diarrhea virus (BVDV) and the border disease virus (BDV) of sheep belong to Pestiviruses, the CSFV possessing a one-sided antigenic relation with the BDV (anti-BVDV antibodies are able to neutralize CSFV) [2]. It is already known that almost all the batches of untreated bovine sera do contain the CSFV neutralizing anti-BVDV antibodies, the CSFV accumulation level during its in vitro cultivation being markedly decreased [3].

The goal of this work was to study the CSFV reproductive cycles and its accumulation dynamics in an established monolayer cell culture, PK-15 (of swine kidney origin). To realize such an investigation we were to take into consideration all the data mentioned above.

That is why a fluorescent probe technique (FPT) has been used permitting to study in vitro virus reproduction even without any detectable CPE 14$8 \mathrm{j}$. Besides, in our investigation a bovine serum batch has been taken for virus-producing cell cultivation 
freed previously from antibody fraction by the polyethylenglycol (PEG) treatment [9]; the absence of anti-BDV antibodies permits to increase the CSFV titers following this pathogen in vitro cultivation [10].

Materials and Methods. Virus. This study was made using two virulent CSFV strains - Alfort (received from the National Veterinary Research Institute in Pulawy, Poland) and Shi-min' (a kindly gift of the Epizootology Laboratory of our Institute) as well as a vaccine strain LK-K (received from the Vaccine Preparations Laboratory of our Institute) adapted previously to the PK-15 cell line.

Cell culture. The cells of the PK-15 line were grown forming a monolayer in the MEM-Eagle medium supplemented by hemohydrolysate and $10 \%$ RPMI as well as by PEG-treated bovine serum $(5-7,5 \%$ ) (the untreated serum, batch 4 , had been purchased from the Konotop slaughter-house, Ukraine).

Cell infection and cultivation. In our experiments the PK-15 monolayer cultures grown in penicillin vials (PVs) were washed three times by a supporting serum-free medium and then infected by the CSFV strains listed above; the infecting virus doses are given in the Table. The virus adsorption was made during $1 \mathrm{~h}$ at $37^{\circ} \mathrm{C}$. Free virus particles present in the medium were washed out (three times), and the supporting medium containing the PEG-treated serum (2 \%) was added into each PV. Three first virusinfected PVs (for each strain) were frozen at once, the rest of them were incubated then in a thermostat $\left(37^{\circ} \mathrm{C}\right)$ and three PVs for each strain were randomly taken from the thermostat in $3,5,7,19,24,48,72$, 96 , and $120 \mathrm{~h}$ following the beginning of incubation. All the PVs were thrice frozen-thawed and then three PVs culture media (for each strain and each time of cultivation) were united and clarified by centrifugation, the supernatant fluids were then used for titration. Control PV cultures were incubated without any strain infection.

Virus titration. The summary virus strain yields (intra- and extracellular) were determined by titration in PK-15 suspensions pretreated by a fluorescent probe to realize the FPT as described early [4-8]. The cell photometry was made using a «LUMAM I-2» fluorescent microscope supplemented by a special equipment unit, FMEL-1 (LOMO, Sankt-Petersburg). An average value of the fluorescence intensity observed in probe-treated intact cells ( 25 or more) is taken as a unit of fluorescence. The fluorescence $K$ value is used to simplify the calculation of results. $K$ is a ratio of the fluorescence intensity of tested (infected) cells $\left(F_{1}\right)$ to the fluorescence intensity of control ones $\left(F_{c}\right)$ :

$$
K=F_{1} / F_{c^{*}}
$$

The $K$ values above or equal to 1.5 indicate the presence of the virus tested in a sample investigated. The values below 1.5 prove the absence of the virus tested or its neutralization by specific (antiviral) antibodies in homologous systems containing both virus particles and immune serum. The diagnostical values of the $K$ criterion have been originally determined to correspond to the $\mathrm{P} \leq \mathbf{0 . 0 1}$, i. e. the statistical significance of results obtained is $99.9 \%$.

The experiments described above were realized three times with each CSFV strain.

Results and Discussion. Our results confirm no CPE takes place during any CSFV strain reproduction in vitro. The data concerning three virus strains (Alfort, Shi-min', LK-K) titrations during $120 \mathrm{~h}$ of their cultivation are given in the Table and in the Figure.

Our investigations concerning extracellular and intracellular virus titers following virus absorption show the infectious virus of any strain studied to be bound by infected cells, no infectious virus particles

Dynamics of the CSFV accumulation in PK-15 cell line according to the titration using the fluorescent probes technique

\begin{tabular}{|c|c|c|c|c|c|c|c|c|c|c|}
\hline \multirow{2}{*}{ CSFV stratn } & \multirow[t]{2}{*}{ CSFV } & \multirow[t]{2}{*}{ titers $(\mathrm{Ig} \mathrm{TC}$} & \multirow{2}{*}{$\frac{\mathrm{LD50} / \mathrm{ml} \pm m)}{5}$} & \multirow{2}{*}{$\begin{array}{c}\text { following PK-15 } \\
7 \\
\end{array}$} & \multirow{2}{*}{\multicolumn{2}{|c|}{\begin{tabular}{|c|c|}
5 monolayer culture iffection \\
19 & 24 \\
\end{tabular}}} & \multirow{2}{*}{\multicolumn{2}{|c|}{ 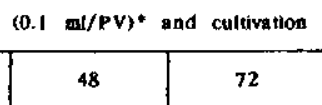 }} & \multicolumn{2}{|c|}{ during (time. hours) } \\
\hline & & & & & & & & & 96 & 120 \\
\hline Alfort & $1.67 \pm 0.33$ & $1.0 \pm 0.33$ & $1.0 \pm 0.0$ & $2.0 \pm 0.5$ & $5.0 \pm 0.5$ & $3.5 \pm 0.5$ & $4.5 \pm 0.5$ & $2.5 \pm 0.84$ & $5.5 \pm 0.29$ & $6.5 \pm 0.5$ \\
\hline Shi-min' & $3.0 \pm 0.33$ & $2.0 \pm 0.33$ & $2.0 \pm 0.0$ & $3.0 \pm 0.33$ & $4.0 \pm 0.5$ & $2.0 \pm 0.5$ & $3.0 \pm 0.33$ & $2.0 \pm 0.29$ & $5.0 \pm 0.5$ & $4.0 \pm 0.33$ \\
\hline LK-K & $4.0 \pm 0.58$ & $2.0 \pm 0.84$ & $2.0 \pm 0.0$ & $3.0 \pm 0.33$ & $4.0 \pm 0.33$ & $4.67 \pm 0.33$ & $6.0 \pm 0.5$ & $6.0 \pm 0.5$ & $7.3 \pm 0.33$ & $8.3 \pm 0.33$ \\
\hline
\end{tabular}

*The infecting doses are 4.5, 4.0, and $5.0 \mathrm{lg}$ TC ID 50 for the strains Alfort, Shi-min', and LK-K, respectively. 


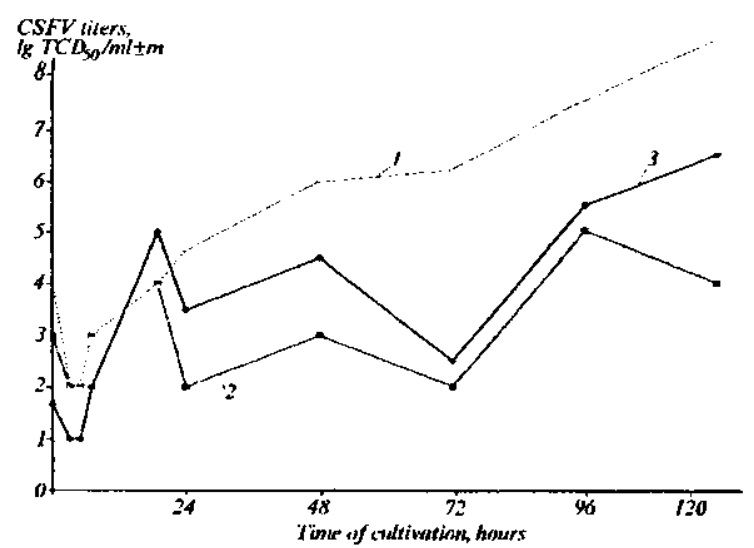

Dynamics of the CSFV accumulation in PK-15 cell line according to the titration using the fluorescent probes technique. Three strains Alfort ( $I$, Shi-min' (2), and LK-K (3) - have been used in these in vitro experiments, the infecting doses being $4.5,4.0$, and $5.0 \mathrm{lg}$ TC $\mathrm{ID}_{50}$, respectively. See also the Table

being washed out. No extracellular virus has been found in any case.

During the first $3 \mathrm{~h}$ of virus cultivation the levels of infectious virus particles are decreased by 1.0, 2.0, and $2.5 \mathrm{lg}$ TC $\mathrm{ID}_{50} / \mathrm{ml}$ for the Alfort, Shi-min', and LK-K strains, respectively. The first new infectious particles are shown to appear in $7 \mathrm{~h}$ p. i., every virus strain titer becoming higher by $1 \mathrm{lg} T C \mathrm{ID}_{50} / \mathrm{ml}$ comparing to virus titers in 3 and $5 \mathrm{~h}$ p. i. Further all three strains reach their lag phase. Both virulent CSFV strains show to have three reproduction peaks (in 19, 48, and $120 \mathrm{~h}$ p. i. for the strain Alfort and in 19, 48, and $96 \mathrm{~h}$ p. i. for the strain Shi-min'). The virulent strain titers are found to decrease in 24 and $72 \mathrm{~h}$ p. i. (by $1.5-2.0 \mathrm{lg} \mathrm{TC} \mathrm{ID}_{50} / \mathrm{ml}$ in the Alfort-infected cultures and by $2.0-1.0 \mathrm{lg}$ TC $\mathrm{ID}_{50} / \mathrm{ml}$ in the Shi-min'-infected ones) comparing to their peak levels.

The maximal Shi-min' yield $\left(10^{5} \mathrm{TC} \mathrm{ID}_{50} / \mathrm{ml}\right)$ is detected for the third reproduction peak in $96 \mathrm{~h}$ p. i., the virus level being $1 \mathrm{lg}$ TC $\mathrm{ID}_{50} / \mathrm{ml}$ lower in $120 \mathrm{~h}$ p. i. Such data are thought to be due to the beginning of the forth reproduction cycle. The strain Alfort is found to increase continuously its infectious level during two last days of cultivation (in $96-120 \mathrm{~h} \mathrm{p}$. i.) and to reach its maximal yield (106.5 TC $\left.\mathrm{ID}_{50} / \mathrm{ml}\right)$ in $120 \mathrm{~h} \mathrm{p}$. i.; it is $4 \mathrm{lg}$ higher comparing to the Alfort infectious level in 72 h p. i., no decrease tendency having been seen. So both virulent strains give similar curves of reproduction and accumulation dynamics during $120 \mathrm{~h}$ of cultivation, the yields of the Alfort particles being higher comparing to the Shi-min' ones.

The obtained curve of the vaccine LK-K strain reproduction and dynamics being similar to virulent strain curves up to the $19^{\text {th }} h$ p. i. becomes later markedly different due to the absence of pronounced reproduction peaks (see Figure). Following the $7^{\text {th }}$ hour of the LK-K cultivation its titers become continuously higher up to the $120^{\text {th }} \mathrm{h}$ p. i. Only in 48 and $72 \mathrm{~h}$ p. i. this strain titers are the same although they are high enough in these points $\left(6 \mathrm{lg} \mathrm{TC} \mathrm{ID}_{50} / \mathrm{ml}\right)$. It is also interesting the $\mathrm{LK}-\mathrm{K}$ yields tested later than $24 \mathrm{~h}$ p. i. are always higher comparing to both virulent strain titers, the difference reaching $1.8-3.3 \mathrm{lg}$ TC $\mathrm{ID}_{50} / \mathrm{ml}$ in $120 \mathrm{~h}$ p. $\mathrm{i}$.

Our results are not contradictory to other information concerning the CSFV latent phase duration, the period necessary for the new infectious virus appearance and the lag-period lasting during the first virus reproduction cycle $[1,11]$. However, our data for more long-term CSFV cultivation differ markedly from those ones published earlier because of the absence of the reproduction plateau during several days of our experiments; such a plateau was found by other authors in $24-60$ or even in $120 \mathrm{~h}$ p. i. followed by a stepwise decrease of virus titers $[11,12]$. We demonstrate in this paper three reproduction peaks during virulent strains propagation in vitro during $120 \mathrm{~h}$ and the exponential increase of the vaccine LK-K strain multiplication without any plateau reaching. We demonstrate also a marked decrease of virus titers for the last reproduction period (120 h p. i.) in experiments with two strains among three ones studied.

Our results prove great possibilities of the FPT approach proposed here and of our methodology permitting to study the in vitro CSFV propagation and accumulation dynamics. We think they to be adequate for the optimization of the large-scale virus cultivation aimed for vaccine production according to international standards [13] as well as for stepwise express production control of virus raw material and anti-CSFV vaccines.

Acknowledgement. We are indebted to Dr. Pavlo Shtchurenko («Diaproph-Med», Kyiv) for his expert help with this manuscript.

Л. Д. Решетиях, С. о. Краснобасв, С. В. Новожилова, E. M. Жеребцова, Г. A. IIonoва

Вивчення циклів репродукці1 та динаміки накопичення вірусу класичної чуми свиней в культурі клітин РК-15 за допомогою методу флюоресцентних зондів

\section{Резюме}

Розроблено вахливу для вирішення біотехнологічних проблем 
методологію вивчення чиклів розмнохення та динаміки накопичення вірусу кгасичної чуми свиней в культурі перевивних клітин PK-15 за умов відсутності будь-яких проявів цитопа. тогенної дї̈ вірусу. Підтверджено мохливість иироко викори стання з цією метою перспективного та надійного методу флюоресцентних зондів, цо не потребус попередньої адаптацї інфекційного чинника до чутливої культури та подальшого його розмнохення в нутливих ктітинах.

Л. Д. Решетняк, Е. А. Краснобаев, Е. В. Новожилова,

9. H. Жеребцова, $\Gamma$. A. Ilonoвa

Изучение циклов репродукции и динамики накогления вируса классической чумы свиней в культуре клеток PK-15 при помощи метода флюоресцентных зондов

Резюме

Разработана вахная для решения биотехнологических проблем методолосия изучения циклов размножения и динамики накопления вируса классической чумы свиней в культуре перевиваемых клеток РК-15 в условиях, когда отсутствуют какие-либо проявления цитопатического действия вируса. Подтверхдена возмохность иирокого использования с зтой челью перспективного и надехного метода флюоресцентных зондов, не требукоцего предварительной адаптации инфекционного агента к чувствительной культуре и последующего его размножения в чувствительных клетках.

\section{REFERENCES}

1. Danner K, Bachmann P. A. Vermehrung und Ausbreitung von Schweinepest-Virus, Stamm Munchen 1, in PK-15 Zellkulturen // Zbt. Vet. Med., Reihe B. -1970.-17, N 3.-S. 353-362.

2. Siurin V. N., Bielousova R. V., Fomina N. V. Classical swine fever // Diagnostics of animal viral diseases (a Reference book).-Moscow: Agropromizdat, 1991.-P. 352-387 (in Russian).

3. Vitin V. G., Tchermashentsev V. I., Rudabelski T. V., Leontieva N. A., Shevchenko $L$ V., Tchermantseva N. A. The effect of different cultivation conditions on the accumulation of the vaccine classical swine fever virus in a cell culture // Probl. of Veterinary Virol., Microbiol. and Epizootol.: Abstr. Conf. All-Russian Res. Inst. Veterinary Virol. Microbiol.m-Pokrov, 1992.-P. $121-122$ (in Russian).

4. Novozhiliva $E$. V. Express indication and identification of some animal viruses and antiviral antibodies // Veterynama medytsyna Ukrayiny. - 1997.-N 4.-P. 36-38 (in Ukrainian).

5. Mishtchenko V. A., Dudnikov A. I., Zakharov V. M., Novozhilova E. V., Bazarov M. A., Prokhorianova Ye. V., Smirnov A. B., Babkin V. F., Bielokon' V. S. Kulbit R. I., Mietlikina N. A., Kamalova N. Ye., Baborenko Ye. P., Tiurina $T$. V. Use of fluorescent probes for the identification of some viruses and antibodies to them // Voprosy virusologii.- $1995 .-\mathrm{N} 1 .-$ P. 12-14 (in Russian).

6. Novozhilova E. V., Krasnobayev E. A., Grishok L. P., Popova $G$. A. Express indication and identification of the classical swine fever virus by a ftuorescent probe using the PK-15 cel] suspension // Abstr. Int. Res. Conf. «Classical swine fever: Actual problems and practical approaches" (9-14 November 1994).-Pokrov, 1995.-P. 58 (in Russian).

7. Novozhilova E. V., Krasnobayev E. A., Grishok L. P. Evaluation of possible use of fluorescent probes and fluorescent antibody techniques for the indication and identification of the classical swine fever virus // Abstr. All-Russian Sci.-Pract. Conf. *Viral diseases of domestic animats* (Vladimir, April, 1995).-Wladimir, 1995.-P. 43 (in Russian).

8. Novozhilova $E$. V., Krasnobayev $E$. A. Express indication and identification of the classical swine fever virus (CSFV) using a fluorescent probes technique and a modified neutralization reaction // Veterynama medytsyna Ukrayiny.-1997.N 11.-P. 37-40 (in Ukrainian).

9. Igudin L. I., Markman G. A., Loban' S. A., Pozina I. M., Migunov $V . N$. Polyethylenglycols and their use in biology and medicine // Zhurnal mikrobiologii, epidemiologii i immunologii. $-1984 .-N$ 4. - P. $17-21$ (in Russian).

10. Reshetniak $L, D$. The effect of bovine serum purification on the classical swine fever virus accumulation in a permissive swine cell line, PK-15 // Laboratorna Diagnostika. $\rightarrow 2000 .-\mathrm{N} 1 .-$ P. 3-5.

11. Van Oirschot $J$. $r$. Classical swine fever virus // Diseases of Swine.-Ames, 1986

12. Buonavoglia C., Falcone E., Pestalozza S. et al. Susceptibility of a minipig kidney cell culture (MPK) to hog chotera // Microbiologica.-1988.-11, N 3.-P. 263-264.

13. Classical swine fever // OIE Manual of standards for diagnostic tests and vaccines.-Paris, 1996. - 3rd ed.-P. 145-154.

УДК 619:616.98:578.833.31 Received 09.07.98 